\title{
Delayed Descemet's membrane detachment after successful cataract surgery: a case report
}

\author{
Descolamento tardio da membrana de Descemet após \\ cirurgia de catarata sem intercorrências: relato de caso
}

Aileen Walsh', Ana Luiza Biancardi², Armando Stefano Crema ${ }^{3}$

\begin{abstract}
The detachment of Descemet's membrane can be a serious complication following cataract surgery, leading to severe corneal edema and reduced visual acuity. This report describes an unusual case of Descemet's membrane detachment 6 months after successful phacoemulsification, documented by anterior segment optic coherence tomography (OCT; RTVue, Optovue). The eye was treated successfully with pneumatic descemetopexy and transcorneal suturing, with reattachment of Descemet's membrane. This report should alert physicians that delayed corneal edema can be related to late-onset Descemet's membrane detachment, which requires proper treatment to avoid permanent corneal decompensation.
\end{abstract}

Keywords: Descemet membrane/pathology; Corneal edema/etiology; Phacoemulsification/adverse effects; Postoperative complications; ; Tomography, optical coherence; Case reports

\section{Resumo}

O descolamento da membrana de Descemet pode ser uma complicação grave após a cirurgia de catarata, resultando em edema de córnea e redução da acuidade visual. Este relato descreve um caso raro de descolamento da membrana de Descemet seis meses após cirurgia de catarata com facoemulsificação sem intercorrências, documentado com tomografia de coerência óptica do segmento anterior (OCT; RTVue, Optovue). Foram realizadas descemetopexia pneumática e sutura corneana, com resolução do descolamento e recuperação visual. Este relato procura alertar os médicos que o edema de córnea tardio pode estar relacionado ao descolamento tardio da membrana de Descemet, que exige tratamento adequado para evitar descompensação corneana permanente.

Descritores: Lâmina limitante posterior da córnea/patologia; Edema da córnea/etiologia; Facoemulsificação/efeitos adversos; Complicações pós-operatórias; Tomografia de coerência óptica; Relatos de casos

\footnotetext{
${ }^{1}$ Mestre em Oftalmologia pela Universidade Federal do Rio de Janeiro (UFRJ) - Rio de Janeiro (RJ), Brasil; ${ }^{2}$ Mestre em Oftalmologia pela Universidade Federal do Rio de Janeiro (UFRJ) - Rio de Janeiro (RJ), Brasil; ${ }^{3}$ Professor Assistente da Universidade Gama Filho (UGF) - Rio de Janeiro (RJ), Brasil.
}

Walsh \& Crema Clínica e Microcirurgia Ocular - Rio de Janeiro (RJ), Brasil

Interest conflict - None

Recebido para publicação em 7/4/2011 - Aceito para publicação em 19/10/2011 


\section{INTRODUCTION}

$\mathbf{T}$

Whe detachment of Descemet's membrane can be a serious complication following cataract surgery, leading to severe corneal edema and reduced visual acuity. The exact pathogenesis of this complication remains unclear. This report describes an unusual case of Descemet's membrane detachment 6 months after successful phacoemulsification.

\section{Case Report}

A 77-year-old female underwent uncomplicated phacoemulsification and single-piece hydrophobic intraocular lens (IOL) implantation (Acrysof ${ }^{\circledR} \mathrm{SN} 60 \mathrm{WF}$ ) in the right eye (OD). A $2.2 \mathrm{~mm}$ temporal clear corneal incision was performed without complications. After one week, her best corrected visual acuity (BCVA) was 20/20 OD with - $0.50 \mathrm{sph}$. Six months later, she complained of a gradual, painless loss of visual acuity. Her BCVA was 20/40 OD and a slit lamp examination revealed localized corneal edema, extending from the side port incision to the central area (Figure 1A). A fundus examination and intraocular pressure were within normal limits. The patient underwent anterior segment optic coherence tomography (OCT; RTVue, Optovue), which showed localized corneal thickening on the pachymetric map (Figure 1B) and detachment of Descemet's membrane adjacent to the superior temporal corneal side port wound (Figure 1C). The eye was treated successfully with pneumatic descemetopexy and transcorneal suturing with 10.0 nylon in the paracentesis, which was the site of the detachment, leading to the reattachment of Descemet's membrane. The cornea was clear at the 2-week follow-up, and the final BCVA was 20/20 OD (Figure 2).
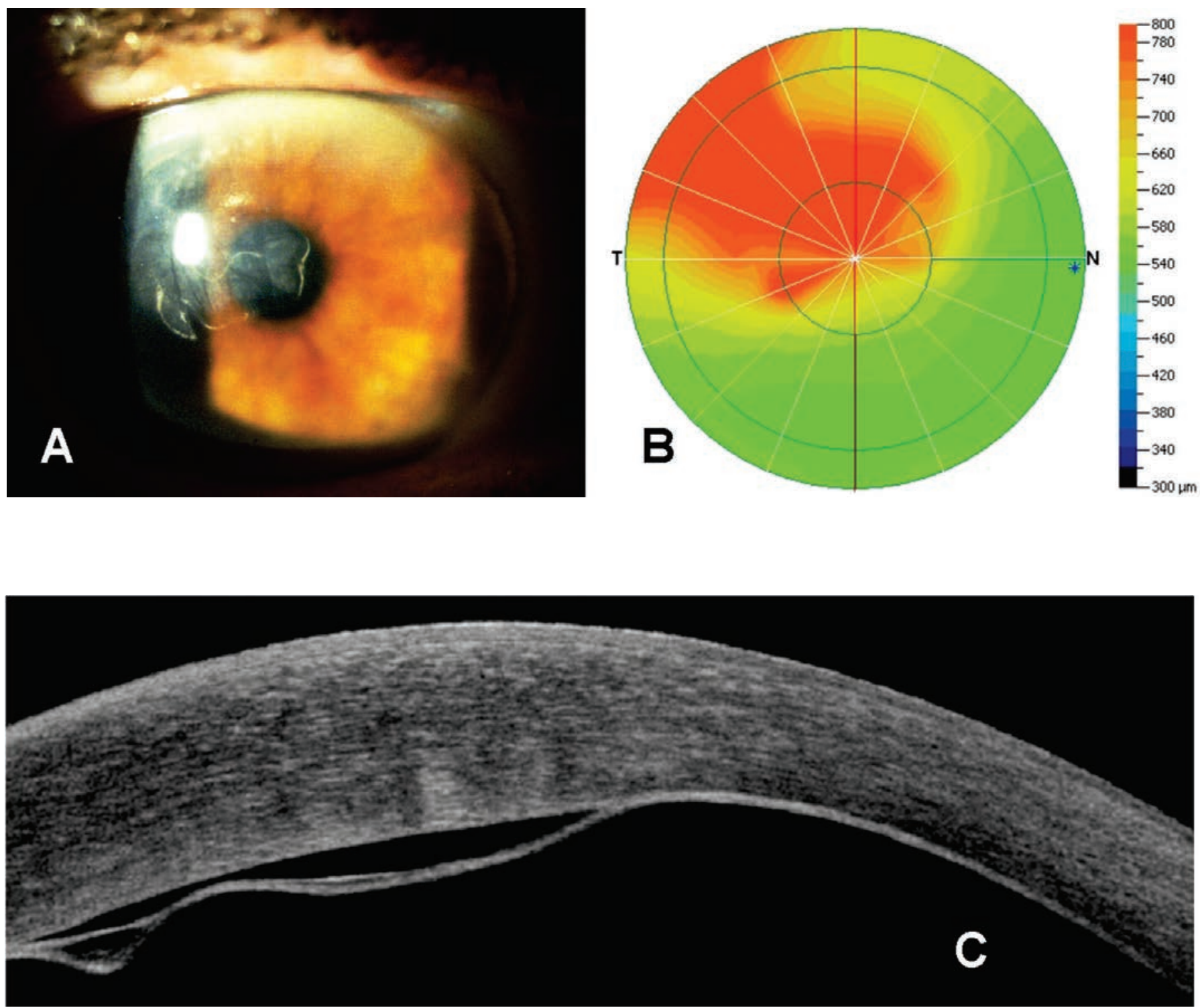

Figure 1:A) Localized corneal edema, extending from the side port incision to the central area; B) Pachymetric map of the cornea, showing the localized corneal thickening; C) Descemet's membrane detachment adjacent to the superior temporal corneal side port wound 

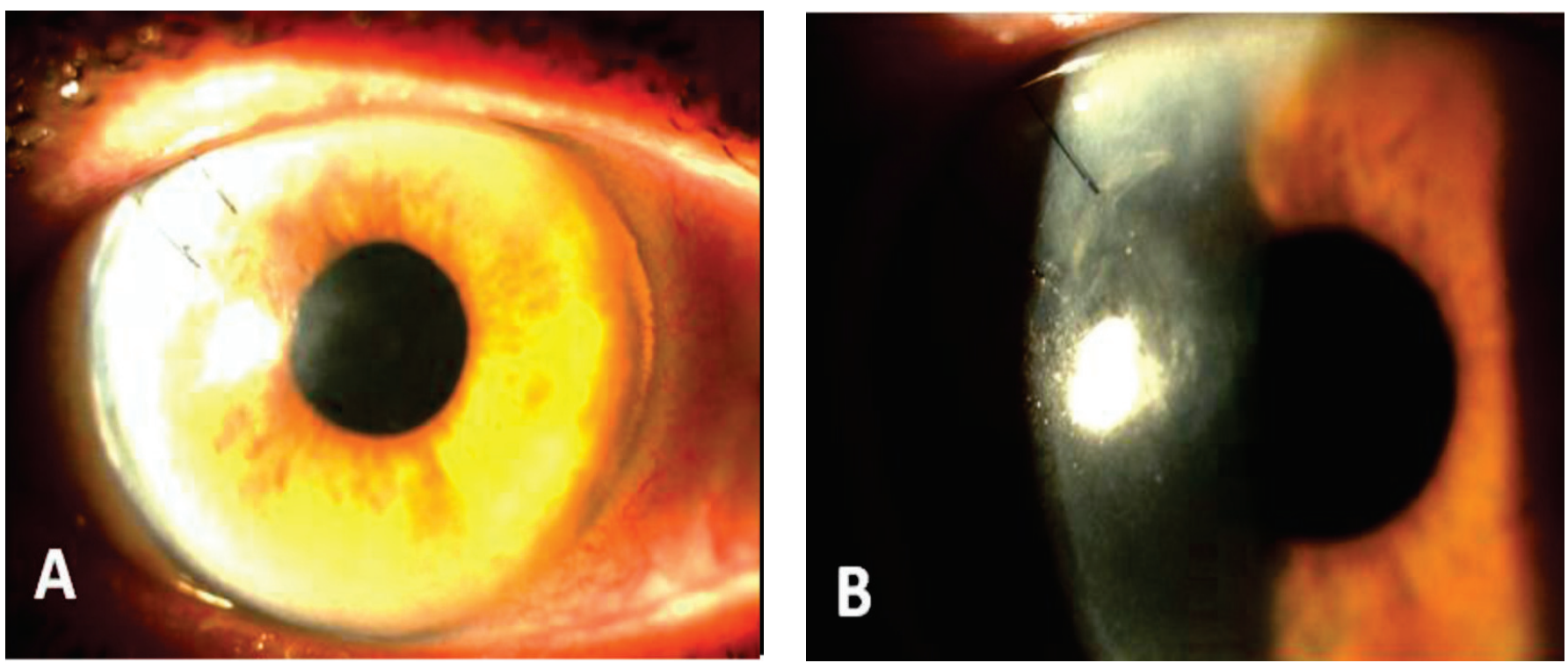

Figure 2: A and B - Transcorneal suturing with 10.0 nylon in the paracentesis and reattachment of Descemet's membrane

\section{Discussion}

Descemet's membrane detachment is common immediately after cataract surgery; however it is usually small, with minimal effect on visual acuity.

Some reports have suggested that Descemet's membrane detachment is related to an anatomic predisposition, such as endothelial abnormalities or surgical procedures, including instrument trauma..$^{(1-3)}$

There are a few reports of patients developing delayed Descemet's membrane detachment after phacoemulsification. ${ }^{(4-}$

6) In our case, OCT was a useful adjunct diagnostic tool for diagnosing Descemet's membrane detachment and demonstrating the anatomic relationship between this complication and the clear corneal wound.

Although some authors have reported spontaneous resolution of Descemet's membrane detachment, ${ }^{(6,7)}$ in our case, the intracameral injection of air and corneal suturing were successful at preventing fibrosis and resulted in the restoration of excellent visual acuity.

This report should alert physicians that delayed corneal edema can be related to late-onset Descemet's membrane detachment, which requires proper treatment to avoid permanent corneal decompensation.

\section{REFERENCES}

1. Kansal S, Sugar J. Consecutive Descemet membrane detachment after successive phacoemulsification. Cornea. 2001;20(6):670-1.

2. Fang JP, Amesur KB, Baratz KH. Preexisting endothelial abnormalities in bilateral postoperative descemet membrane detachment. Arch Ophthalmol. 2003;121(6):903-4.

3. Marcon AS, Rapuano CJ, Jones MR, Laibson PR, Cohen EJ. Descemet's membrane detachment after cataract surgery: management and outcome. Ophthalmology. 2002;109(12):2325-30. 4. Gatzioufas Z, Schirra F, Löw U, Walter S, Lang M, Seitz B. Spontaneous bilateral late-onset Descemet membrane detachment after successful cataract surgery. J Cataract Refract Surg. 2009;35(4):778-81.
5. Banitt MR, Malta JB, Shtein RM, Soong HK. Delayed-onset isolated central Descemet membrane blister detachment following phacoemulsification. J Cataract Refract Surg. 2008;34(9):1601-3.

6. Couch SM, Baratz KH. Delayed, bilateral descemet's membrane detachments with spontaneous resolution: Implications for nonsurgical treatment. Cornea. 2009;28(10):1160-3.

7. Iradier MT, Moreno E, Aranguez C, Cuevas J, García Feijoo J, Garcia Sanchez J. Late spontaneous resolution of a massive detachment of Descemet's membrane after phacoemulsification. J Cataract Refract Surg. 2002;28(6):1071-3.

\author{
Autor correspondente: \\ Ana Luiza Biancardi \\ Avenida Ataufo de Paiva, n $245,1^{\circ}$ andar - Leblon \\ Rio de Janeiro (RJ),Brasil \\ e-mail: albiancardi@ig.com.br
}

